bology Laboratory at Risley had been awarded for four years "because ESRO's financial future after 1975 is uncertain". The initial period of financing was determined by budget release policy and not by any uncertainty as to the availability of funds after 1975.

Last December the ESRO Council unanimously approved not only the Organization's 1972-74 budget but also a substantially increased provisional total level of resources of $\$ 110$ million a year for the three-year period 1975-77. The Council authorized ESRO to spend not less than $\$ 70$ million a year on application satellites alone during the period 1974-80.

$$
\text { Yours faithfully, }
$$

P. M. BRown

European Space Research Organization, 114 Avenue Charles-de-Gaulle (92), Neuilly-sur-Seine

\section{Knuckle Walking}

SIR,-The delightful ambiguities that can be produced by simple combinations of English (British/American) words and phrases are never-ending. A case in point is found in the recent correspondence (Nature, 236, 472; 1972) from $\mathrm{Mr}$ Tiratsoo referring to the knuckle walking article earlier (Nature, 236, 34; 1972). Mr Tiratsoo, obviously reared in the realm of British football, confuses the authors' expression ". . . football linesmen" . . . as meaning the official who in British-style football prances about (handsomely attired!), waving his little flag and (sometimes?) clutching a stop-watch. What the authors meant, and what must be obvious to an American reader, is the American football lineman-a tackle, guard, or centre who assumes a tripodal stance, cleated feet dug in, one hand in a semi-fist, crouched and ready for the mayhem of scrimmage. In this stance the fingers are knuckled urıder, pressing into the turf (artificial?) before the snap of the ball from centre. The fingers are knuckled under to avoid the extremely painful injury that can result from having the opposing lineman (275 $\mathrm{lb}$ and up) step on outspread fingers. Most American football linemen bandage the hands so that only the knuckle stance is possible. Phrases, like landscapes, are always comprehended with respect to the pointof-view!

Yours faithfully, C. E. LoNG

Nuclear Effects Laboratory, Kirtland $A F B$,

New Mexico

\title{
Obituary
}

\section{Professor J. S. Griffith}

THE death of Professor John Stanley Griffith at Cambridge on April 23, 1972, at the early age of 43 , has brought to an end a remarkably varied career. The fact that his father was a distinguished bacteriologist and his mother a graduate in mathematics and physics may have encouraged him to think widely and discard traditional limitations in his research. In 1948 at Trinity College, Cambridge, he obtained a brilliant firstclass in the mathematical tripos. This led to a Rouse Ball studentship, also at Trinity, and the opportunity to take Parts I and II of the biochemistry tripos. His early research was with Sir John Lennard-Jones at Cambridge, and then with Professor C. A. Coulson at Oxford. During this time he was a Senior Demy at Magdalen College. A year of national service at the Admiralty Research Laboratory studying the formation of droplets and the magnetic properties of certain materials was followed by the Stokes Studentship at Cambridge, the Berry-Ramsey Fellowship in Mathematics at King's College, Cambridge, and a series of chairs, first in chemistry at the University of Pennsylvania, then in mathematics at the Manchester College of Science and Technology, and at Bedford College, London. This finally led to a chair of chemistry at Bloomington, Indiana, and-for the last few months of his life-membership of the Institute of Immunology at Basle.

This varied professional career showed itself in his research. His early work was in theoretical chemistry, where he made useful contributions to the newly-developed free-electron model for conjugated molecules, and to the spatial correlation of electrons in atoms. But by 1954 he had begun to turn his attention towards inorganic chemistry. The astonishing upsurge of interest in ligand-field theory which occurred in the late $1950 \mathrm{~s}$ was in no small measure due to John Griffith and Leslie Orgel. Orgel concentrated on the more pictorial and descriptive aspects, Griffith on the basic principles. His immense book The Theory of Transition Metal lons (1961) was a magnificent piece of work, and for the first time really established the subject on a solid theoretical basis. In it he rationalized the magnetic and optical properties of molecular complexes, taking proper account of temperature effects and spin-orbit interaction. Ten years later it still remains the definitive work in this field. This phase of his life was rounded off by a second book, The Irreducible Tensor Method for Molecular Symmetry Groups (1962).

By this time he was getting deeply interested in biological matters. The connecting link was the magnetic property of the combination of oxygen with haemoglobin. How could ligandfield theory account for the newly observed electron-spin resonance spectrum of ferric haem in myoglobin, with peaks at $g=6$ ? What was the electronic structure of the bond between oxygen and ferrous ion? One fact which had to be explained was that oxyhaemoglo- bin was diamagnetic, while oxygen itself is paramagnetic. Griffith showed that there were two possible answers. The one, which he preferred, was completely original, and postulated a symmetrical structure, with the iron-oxygen bond perpendicular to the oxygen-oxygen bond. The other was a reinterpretation of Pauling's bent bond structure, translated into molecular-orbital terms. Griffith's interpretation of the electronspin resonance spectra was immediately accepted, and proved most valuable. His symmetrical model for oxygen binding now seems less likely to be correct, but the question remains open. Recent work on the structure and spectra of haem compounds, including cobalt haemoglobin, suggests that molecular oxygen binds as a superoxide ion, and that many of Griffith's ideas are still relevant.

It was also in the early sixties that he became progressively more interested in the possible contributions that mathematicians could make to studies of the central nervous system. A few of his colleagues tried to dissuade him from moving into this field, but he persisted and was indeed to be followed by some of them. He left Philadelphia and returned to Cambridge to begin his work in earnest. First he studied the statistical properties of spontaneous impulse activity in cortical cells and the way in which activity in a neurone influences the excitability of an adjacent neurone. This work was closely tied to experimental observations.

At the same time he developed a field theory for predicting the overall be- 
haviour of impulse activity in neural networks, which he described by local differential equations. $\mathrm{He}$ became interested in neuronal differentiation and suggested a molecular basis for the differences between classes of nerve cells. $\mathrm{He}$ considered that an alteration in the connexions between neurones is the most plausible theory for the neural basis of memory and turned to consider how such alterations could be initiated. In his "two gates" hypothesis he suggested that when two synaptically coupled cells fire together, their membranes become permeable to a chemical messenger substance which passes across the synapse from one cell to the other. He then went on to show how such a substance might act in order to change the functional connexions between the two cells. This was probably his most important contribution to brain theory. It created widespread interest although, because of technical difficulties, it remains to be tested. In 1967 he produced a short monograph entitled A View of the Brain, presenting, among other things, some controversial ideas about the establishment of connexions in the visual system, and 1971 saw the publication of his last book, completed during his long final illness, entitled Mathematical Neurobiology, in which he outlined the mathematical theory of neuronal networks, of action potentials and of information storage systems in general. It will be some time before the full implications of Griffith's original contributions to this subject are fully worked out.

No account of John Griffith's life would be complete without a reference to his deep passion for mathematical purity, his thoroughly original approach to any problem in which he was interested, and - behind a somewhat reserved exterior - a quiet shy smile that endeared him to his friends.

\section{Announcements}

\section{International Meetings}

July 2-14, Padé Approximants and their Applications, Canterbury (Dr A. K. Common, School of Mathematics, University of Kent, Canterbury, Kent).

July 3-4, Advances in Applied Spectroscopy, London (Conference Administrator, IPC Business and Industrial Training Limited, 161-166 Fleet Street, London EC4).

July 3-5, Band Structure in Solids, Exeter (Professor E. P. Wohlfarth, Department of Mathematics, Imperial College, London SW7).

July 3-5, British Society for the History of Science Meeting, Exeter (Assistant Secretary, British Society for the History of Science, 47 Belgrave Square, London SW1).

July 3-7, Models, Evaluations and Information Systems for Planners, Canıbridge (Richard Baxter, Centre for Land Use and Built Form Studies, 16 Brooklands Avenue, Cambridge CB2 2BB).

July 3-7, Tropical Hygiene, London (Ross Institute of Tropical Hygiene, London School of Hygiene and Tropical Medicine, Keppel Street (Gower Street), London WC1E 7HT).

July 3-7, Sex Education, Tel Aviv (Dr E. Chigier, PO Box 16271, Tel Aviv, Israel).

July 3-7, Nuclear Magnetic Resonance Spectroscopy, Guildford (Dr John F. Gibson, The Chemical Society, Burlington House, London W1V 0BN).

July 3-8, Chemistry in Evolution and Systematics, Strasbourg (Dr J. B. Harborne, Phytochemical Unit, Botany Department, The University, Reading RG1 5AQ).

July 3-20, Athens Ekistics Month, Athens (P. Psomopoulos, Athens Centre of Ekistics, Box 471, Athens, Greece).

July 3-29, Plasma Physics, Les Houches (Ecole d'Eté de Physique Théorique, 74 Les Houches, Haute Savoie, France).

July 4, The Measurement of Radiative Lifetimes of Atoms and Simple Molecules, Oxford (The Meetings Officer, Institute of Physics, 47 Belgrave Square, London SW1X 8QX).

\section{Reports and Publications}

not included in the Monthly Books Supplement

\section{Great Britain and Ireland}

Centre for Overseas Pest Research. Tropical Pest Bulletin No. 1: Illustrated Descriptions, Distributio Maps and Bibliography of the Species of Quelea (Weaver-Birds: Ploceidae). By Joyce I. Magor and P. Ward. Pp. 23+2 plates. (London: Centre for
Overseas Pest Research, 1972.) £1 net. Overseas Pest Research, 1972.) \&1 net.
Imperial Cancer Research Fund-Annual Report Imperial Cancer Research Fund-Annual Report
and Accounts for 1971. Pp. 77. (London: Imperial and Accounts for 1971. Pp. 77. (London: Imperia
[233 Harwell Industrial Research. Radioisotopes in Industry : Instruments and Tracers. Pp. 12. (LonMental Handicap: a Select Annotated BiblioBucks: National Foundation for Educational Research in England and Wales, 1972.) 40p. 1243 Chemist and Druggist Directory 1972 and Tablet and Capsule Identification Guide. Pp. 332. (Lon-
don: Benn Brothers, Led., 1972.) E6. don: Benn Brothers, Ltd., 1972.) E6. Gardeners' Sunday. White Witches, Claygate Road. 1972.) $10 \mathrm{p}$.

Bellamy on Botany. By David
+ 80. (London: BBC, 1972.) 75p

The Careers Advisory Board of the Universities of Durham and Newcastle-upon-Tyne. Twenty-sixth Annual Report. Pp. 23. (Durham and Newcastle: The Universities, 1972 .) Section A. No. 1: Some Asymptotic Relations fo Starlike Functions. By F. Holland. Pp. 1-16. 30p No. 2: The Idempotent Semigroups of Compact Monothetic Semigroups. By G. Brown and $W$ Moran. Pp. 17-34. 32p. No. 3: The Equation of Motion of Charged Bodies in General Relativity. By P. A. Hogan. Pp. 35-50. 32p. Vol. 72, Section (Diptera) in Ireland, with Observations on the Growth of Three Species. By Edward Fahy. Pp. cian Rocks of Courtown (Co. Wexford) and Tramore cian Rocks of Courtown (Co. Wexford) and Tramore
(Co. Waterford). By W. I. Mitchell, H. Carlisle, (Co. Waterford). By W. I. Mitchell, H. Carlisle, Royal Irish Academy, 1972.) University of East Anglia. Annual Report of the Appointments Board, 1970/1971. Pp. 44. (Norwich:
University of East Anglia. 1972.)

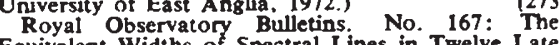
Royal Observatory Bulletins. No. 167: The
Equivalent Widths of Spectral Lines in Twelve Late
F. Dwarfs. By A L. T. Powell. Pp. 303-314. 29p net. No. 168: Spectral Lines for Curve-of-Growth Analysis of Late-Type Stars, I. By A. L. T. Powell.
Pp. 315-350. 50p net. No. 170: Masses, Radii Pp. 315-350. S0p net. No. 170: Masses, Radi and Luminncities of RR Lyrae Variable Stars. By Sir Richard Woolley and Ann Savage. Pp. 363-396. tory, 1971.)

Philosophical Transactions of the Royal Socicty of London. B: Biological Sciences. Vol. 263, No. 85 Palaeontology of Chiloe Island, South Chile. By W. A. Watters and C. A. Fleming. Pp. 369-408+ March 1972): The Organization of a Cephalopod Ganglion. By J. Z. Young. Pp. 409-429+ plates 29-39: E1.40; \$3.90. Vol. 263, No. 855 (16 March 1972): The Genetics of the Mimetic Butterfly Papili polytes L. By C. A. Clarke and P. M. Sheppar No. 856 (23 March 1972): Endemic Goltre in the Dermatoglyphics and Taste-Testing. By J. A. Chapman, I S. Grant, G. Taylor, Khalida Mahmud, Sardar-U1-Mulk and M. A. Shahid. Pp. 459-491+ plates 43-46. £1.15; $\$ 3.20$. (London: The Royal Annual Report of the Paterson Laboratories for 1971. Pp. 144. (Manchester: Paterson Laboratories, Christic Hospital and Holt Radium Institute, The Trees and Woods of Exmoor. By Roge Miles. (Microstudy B2.) Pp. 64+25 photographs. (Dulverton: The Exmoor Press, 1972.) 50p. Natural Environment Research Council. The
Nature Conservancy Research in Scotiand-Report Nature Conservancy Research in Scotiand-Report
for 1968-1970. Pp. vi+98. (Edinburgh: The Nature for 1968-1970. Pp. vi +98. (Edinburgh: The Nature Conservancy, Scottish Headquarters, 1970.) $50 \mathrm{p}$
net. Alcohol and Drug Dependence-Treatment and Rehabilitation. Pp. 99. (London: King Edward's
Hospital Fund for London, 1972.) Fabian Research Series No. 300: Public Enterprise. By Christopher Foster. Pp. 32. (London: Fabian Society, 1972.) 30p.
[44 Ministry of Agriculture, Fisheries and Food Computer. Pp. vi +132. (London: HMSO, 1971.) £1.50.

Philosophical Transactions of the Royal Society of London. A : Mathematical and Physical Sciences. Vol. 272, No. 1220 (3 March 1972): Modern EquaSystems. By T. B. Beniamin. J. L. Bona and J. J. Mahony. Pp. 47-78. (London: The Royal Society, 1972.) 85p; $\$ 2.35$

Fabian fract No. 412: The Politics of the Environment. By Jeremy Bray. Pp. 24. 25p. Fabian babwe. By Kees Maxey. Pp. 40. 45p. (London The Fabian Society, 1972.)
Potato Marketing Board. Sutton Bridge Experimental Station-Annual Review-1971. Pp. 40. Questions and Answers about Potato Gradiog and
Marketing Groups. Pp. 12. (London: Potato MarMarketing Groups. Pp. 12. (London: Potato Mar-
keting Board, 1972.) Family Planning in Britain. Pp. 40. (London Office of Health Economics, 1972.) 25p.
Albright and Wilson. Lid. Annual Report for 1971. Pp. 40. (London: Albright and Wilson, Ltd. 1972.) Pp. 40. (London: Albright and Wilson, Ltd. The Cleaning of Premises and Plant in Accordance with The Asbestos Regulations. (Control and Safety Guide No. 9.) Pp. 12. (London: The Asbestos
[64 Bulletin of the British Museum (Natural History). Zoology. Vol. 22. No. 6: Bats from Thailand and Pp. 171-196. 95p. Vol. 22, No. 7: A Redescrip tion of Spelaeomysis servatis (Fage) Comb. Nov Collected on Aldabra Atoll. with a Key to the Species of Lepidomysidae. By $\mathbf{R}$. W. Ingle. Pp. $197-210.65 \%$.) (London: British Museum (Natura
History), 1972.)

Agricultural Research Council. Weed Research Organization-Fourth Report, 1969-1971. Pp. iv 1972.) (London: Agricultural Research Council.
[74 National Institute for Medical Research. Scientific Report for 1970-71. Pp. iv +114. (London: Medi-
cal Research Council, 1972.) Chemical Socicty. Monographs for Teachers No. 20: Silicon Chemistry and Applications. By C. A Pearce. Pp. v+74. (London: The Chemical Society. 1972.) \&1. Report and Accounts for 1971. Pp. 47. (London: The British Petroleum Company Limited. 1972.) [104 The British Council. Overseas Students in Britain The British Council, 1971.) 10p. Pp. 25. (London: The British Council, 1971.) 10p. for 1971. Pp. 69. (London: The Zoological Society of London, 1972.) Proceedings of the Royal Irish Academy. Vol 72, Section A. No. 4: The Attachment of Radon Daughter Products to Condensation Nuclei. By J. $P$ McLaughlin. Pp. 51-70. 36p. No. 5: The Electronic Spectrum of the Bel Racical. By P. S Murty and P. T. Rao. Pp. 71-79+ plates 1 and 2. 25p. Vol. 72. Section B. No. 8: The Declaration of the Sperrin Mountains and Adjucent Areas in ern Ireland. By E. A. Colhoun. Pp. 91-147+ plates 4-7. 90p. No. 9: An Early-Breeding Population of Fieldanice Apodemus sylvaticus (L.) in Limekiln Wood, Athenry, Co. Galway. By J. S. Fairley and M. E. Comerton. Pp. 149-163. 18p. (Dublin: 